\title{
WHAT IS WRONG WITH TAXICAB INSURANCE RATES?
}

\author{
Frederick U. ANDREs*
}

I

The insurance buyer has long been at the mercy of the seller-the insurer. With the decision of United States $v$. South-Eastern Underwriters Association, ${ }^{1}$ a faint hope arose that at last the federal antitrust laws might be used to bring about a long needed reduction of insurance rates by breaking up the price-fixing combinations by means of which the insurers set the rates. This hope grew fainter with the passage of the McCarran $\mathrm{Act}^{2}$ and died with the passage of the various state regulatory laws.

It is my purpose here to show how the existing pattern of state regulation of insurance favors the insurer to the extreme disadvantage of the insured in but a small segment of the American economy-the taxicab industry. Although the subject of my analysis is but a drop in the economic bucket, there is every reason to believe that the defects found here in state regulation will carry over, and perhaps even be accentuated, in other areas.

The taxicab industry in the United States consists of more than 100,000 cabs, operated by more than 2,000 corporations, partnerships, and individuals with more than 250,000 employees on their payrolls.

This industry is vitally affected by the insurance rates it must pay. During the present period of the ever-upward inflationary spiral, the small taxi operator, who is operating on an almost inflexible schedule of rates, may find himself unable to meet even a slight increase in insurance rates. This situation in itself does not, of course, give the small operator any claim, as of right, to any existing, or lower, rate. This situation does make it imperative that the operator be given the advantage of either a competitively arrived at rate or, at the least, one arrived at by means of a government regulated process in which the insurer is not the dominant participant. A look at the way in which the taxicab operator secures his insurance and the method used to compute the rate would seem to be in order.

II

\section{What Must a Taxicab Operator Do to Get Insurance?}

The operator usually is compelled by state law or local ordinance to maintain liability insurance for his vehicles. He usually is unable to get any underwriter voluntarily to accept his risk. He must, therefore, apply to a pool of insurance carriers, which will assign him to one of its members. The pool ordinarily operates

- Member of the Arkansas bar. Contributor to national trade magazines.

122 U. S. 533 (r944), 44 CoL. L. REv. 772.

259 Stat. 33 (I945), as amended, 6r STAT. 448 (I947), I5 U.S.C. \$§IoII-Io15 (Supp. I949). 
under an experience rating plan which provides for increases or decreases in rates to the insured based upon his individual loss experience.

Since the operator is compelled by law to purchase such insurance, it seems only just that he be given the lowest possible rate consistent with good business. It is my contention that the taxicab operator is practically at the mercy of the insurer with respect to terms and conditions of the policy and the premiums paid.

It is true that most state regulatory laws passed subsequent to the McCarran Act provide that rates must not be excessive, inadequate, or unfairly discriminatory. These laws are capable of providing, and for the most part have provided, nondiscriminatory and adequate rates, but it is submitted that they are not capable of protecting (or at least they have not done so) the insured from excessive rates. This can be made more clear by an examination of some of the most important factors which, of necessity, enter into the computation of the insurance rate.

Prospective losses is one of the most important of these factors. Under the experience rating, or merit, plan, the prospective losses of the insured are determined from his past experience, including both actual and adjusted losses. If the operator was experience rated before he applied to the pool, all adjustments or reserves, no matter how foolish or excessive, set up by his former carrier will be charged to his experience-and this despite the fact that he had no opportunity to intervene in any settlement or to prove the worthlessness of any claim reported against him.

The operator will therefore pay for reserves that may never be expended, and which he cannot recover, and, paradoxically, his new carrier will be collecting for losses that had nothing whatever to do with it or the new policy, because they were sustained before the new policy was written. In addition to the foregoing objections, it is almost a certainty that the carrier, or rating bureau, is going to allow for a comfortable margin of error in calculating prospective losses.

Another factor which enters into the computation of the rate is the cost of acquisition of the policy. In the case of ordinary automobile insurance this cost includes a rather high commission paid to the agent (usually $17 \frac{1 / 2}{2}$ per cent), a commission paid to the state agent (usually $7 \frac{1 / 2}{2}$ per cent), and a contingency based upon the loss ratio. In other words, the cost of acquisition for ordinary automobile policies amounts to at least 25 per cent of the premium collected.

The cost of acquisition of a compulsory taxicab policy obtained through an assigned risk pool should be almost negligible, but the agent receives 5 per cent of the premium-a rather large sum in the case of taxicab insurance. The agent's sole responsibility is to submit a form to the assured for his signature; there his service ends.

The Commissioners' bills provide for the fixing of rates with reference to "a reasonable margin for profit and contingencies" and to "catastrophic hazards." Most of the state regulatory laws enacted after the passage of the McCarran Act provide that consideration be given to a "reasonable margin for underwriting profit and contingencies" and "catastrophic hazards."3

\footnotetext{
"ARk. StAT. c. 66, tit. 419(a)I (1947). (Italics supplied.)
} 
The effect of this divergence from the Commissioners' bills is to exclude a consideration of the carriers' investment profit from rate making, thereby enhancing the profit of the carriers at the expense of the insuring public. The provisions directing consideration of "contingencies" and "all other relevant factors within and without this state" interject elements which are incapable of accurate measurement, and allow the carriers to charge excessive rates-to err in one's own favor is but human.

The short and obvious answer to the above criticism is, of course, that the state insurance commissioner is empowered by the law to see to it that rates are not excessive. The unhappy truth, however, is that usually the principal concern of the insurance commissioner is that the carrier maintains sufficient funds to pay its claims.

Too often the commissioner accepts the carrier's or rating organization's estimate of prospective losses as the "gospel," and he is very lenient with respect to such matters as agents' commissions and allocations for "contingencies" and other "relevant factors." The effect of state regulatory legislation has been to maintain the selling price of insurance. Furthermore, the assured has no day in court or rate hearing before any commission, such as he would have in dealing with a public utility, although because of its status as a member of a state "regulated" price fixing combination, the carrier stands in practically the role of a public utility to the taxicab operator who must purchase its services.

The taxicab operator is impaled on that "proper balance ... between regulated joint action and independent action," which the state regulatory laws patterned after the Commissioners' bills were supposed to achieve. The result of that "proper balance" has been to eliminate competition from the sale of insurance, and to substitute state organized combinations in restraint of interstate commerce which exact excessive rates and as a consequence reap unreasonably high profits.

The insurer of the taxicab operator cannot lose; the operator cannot win. The carrier rates the risk according to the National Bureau of Casualty Underwriters, or some other rating organization, on a recognized permissible loss ratio of 64 per cent. In other words, the expenses of the company for losses incurred or for anticipated losses, including adjustment expenses, may not exceed 64 cents of the premium dollar collected. The remaining 36 cents of the premium dollar is allowed for other expenses and profit. The carrier is guaranteed 36 per cent of all money above claims paid or of reserves set up, or he cancels the operator out.

It is apparent by their ratings and their handling of settlements that the carriers are looking only to their own interests-usually at the expense of their assureds. An operator may wish to defend a few doubtful claims in order to discourage the fictitious type, but his carriers insist upon settling on a nuisance basis or better, because under their set-up they operate on what amounts to a cost-plus basis. They

- Ibid.

'Orfield, Improving State Regulation of Insurance, 32 MinN. L. REv. 219, 232 (1948). 
can usually make more money by paying than by defending. For each 64 cents the carriers pay out in losses, they receive $3^{6}$ cents for themselves. All the costs of defense in addition to the expenses of adjustment must be paid from the $3^{6}$ cents. If settlements are made without litigation, only the adjustment expenses are paid by the carrier from the 36 cents. The carriers therefore stand to increase their margin of profit through settlements.

\section{III}

\section{Who Is HurT?}

Taxicab operators fall into one of two categories: Those operating more than one hundred cabs are known as "large operators," whereas those operating less than one hundred are known as "small operators." The operator, large or small, who has a monopoly in his community is able to control every phase of his operation, including his insurance. His political position and influence with the governing body is such that he is usually able to direct the settlement policy with respect to claims made against him.

The operator in a dominant position, or one who has a near monopoly, is also favored. This exists in cities where the number of license plates is controlled and limited by the city council or city manager, or by the public service or utility commission, and the operator owns a large percentage, say, above half, of the license plates issued. In that situation his competition is restricted from growth, and, therefore, no matter what it does, his operations are not affected to any great extent.

The majority of small operators are doing business in a highly competitive market. They operate in cities where there are no restrictions on the number of operators, and the only requirement is the ability of the licensee to comply with the statutory requirements.

Nearly all large operators are self-insurers, or, if that is legally impossible in their community or state, they own sufficient stock in an insurance company to enable them to control its policy with respect to settlement of their claims. Consequently, the only group of taxicab operators adversely affected by the conduct of the insurance companies at present are the 2300 or more small operators in the United States. These operators, who do business on a competitive basis, operate about 65 per cent of the taxicab equipment in use today-approximately 105,000 cars.

\section{IV}

\section{ConcLusion}

The states have succeeded in forestalling application of the federal antitrust laws to the making of insurance rates. In doing so they have, it is believed, in many instances subordinated the best interests of the people to the selfish interests of the large insurance companies. This condition is apt to lead to that which has always 
been most feared by both the insurers and the states-complete federal control and regulation of the business of insurance.

As previously indicated, I have sought to present the problems of but a small portion of the insuring public. Let us hope that there are not too many others in a similar position. If there are, it may take a long time, but their voices will finally be heard, and the insurers will be in a much worse position for not having cleared up the situation themselves. 